\title{
Arthur Phillip: Commodore of the Fleet
}

Gary L Sturgess

\section{Columbus's Egg}

There is an old story that shortly after his return from the Americas, Christopher Columbus was dining with some Spanish nobles who downplayed the difficulties involved in making this voyage. By way of an answer, he took a raw egg and challenged them to make it stand upon its end. They replied that it could not be done. Columbus then gently tapped the egg so that he broke the shell but not the membrane, creating a flat surface on which the egg could rest. On seeing this, the nobles exclaimed, 'But that is easy!' To which Columbus is said to have replied, 'It is now'. ${ }^{1}$

The transportation of convicts to New South Wales in the early years of settlement, and the First Fleet in particular, was a great deal more challenging than has generally been recognised. Phillip described it as a voyage 'to the extremity of the globe'. As late as 1802, the political philosopher, Jeremy Bentham, compared it to a voyage to the moon: 'The moon was then, as it continues to be, inaccessible; on earth there was no accessible spot more distant than New South Wales'. ${ }^{2}$

Newspaper editors thought that most of the First Fleet convicts would die en route: 'the first land that two-thirds of them will reach, will be the bottom of the sea'. That so many of them arrived in good health came as a great surprise to the military and civilian officers who sailed on that founding voyage. ${ }^{3}$

Ten per cent of the convicts shipped to Australia in the first seven years of settlement perished in the passage. We often speak of the mortality rate on the First Fleet as though it consisted only of the 21 male convicts and three women (around three percent) who died in the course of the voyage. But given that the deaths on the Alexander and Lady Penrhyn prior to sailing arose from diseases loaded on board from the prisons, we should include those and some who died from disease in the weeks after landing, which raises the mortality rate to somewhere in the range of five to nine percent. ${ }^{4}$

And it was not just the convicts: the mortality rate among First Fleet mariners was more than one in five, twice that of the prisoners once time at sea is taken into account. They died of shipboard accidents on the outward voyage and scurvy on the way home. ${ }^{5}$ 
Of the forty-one ships that carried convicts and stores to Australia in the seven years up to 1794, one in six never came home - wrecked on Pacific islands, struck by icebergs in the southern ocean, deliberately sunk because of scurvy, captured by pirates and privateers.

It was the voyage home through the islands of the Pacific or the East Indies that posed the greatest threat to the ships and their crews. But the managerial challenges involved in the outward voyage in those early years were unprecedented transporting hundreds of convicts confined for six to eight months on the lower deck of a merchant ship - unwilling passengers who would mutiny or escape if they were not constrained enough, and perish from disease if they were constrained too much.

When the First Fleet was being commissioned in the spring of 1786, there was no one in British government who had experience with the management of convicts on board a convict transport. ${ }^{6}$ Indeed, there was no one in Britain who had done this for more than a decade, and only one man, Duncan Campbell, who had any experience with convict transportation at all. To the best of our knowledge, no one had ever managed a convoy of six transports carrying more than 750 convicts, and there was certainly no one had tried to manage them on a voyage of eight months duration to the far side of the globe.

This means that we need to rethink the contribution of Arthur Phillip (along with other key figures such as Evan Nepean, the Under Secretary of the Home Office, and William Richards, the First Fleet contractor) in fitting out and managing Australia's First Fleet.

It would take years for best practice to emerge in convict transportation. Improvement was necessarily incremental, and lessons were learned through trial and error, report-back and adjustment, voyage by voyage. This is evident from a study of the 1832 instructions given to the masters and surgeon superintendents of convict ships, and comparing them with the directions given in 1816, 1823 and 1824, and those issued to 'approved surgeons' in 1801 and $1812 .{ }^{7}$

Of course, there was one major exception to this - the First Fleet, where those responsible for commissioning and managing the convicts had no alternative but to innovate on a large scale. It is likely that Arthur Phillip and William Richards spent time with Duncan Campbell and/or the captains of his hulks, learning how to manage convicts confined on board a transport, but their challenge was so much greater and necessarily, the First Fleet must be regarded as a grand experiment.

This paper explores Phillip as a leader and manager of men, and in the spirit of Columbus's Egg, it does so through a series of incidents and anecdotes associated with the outward voyage. 


\section{Commissioning the Fleet}

Historians have long recognised Phillip's great attention to detail in commissioning the First Fleet. In early October 1786, shortly after he was appointed, Phillip took time to think through the management of the convicts in the course of the voyage and later in the settlement. While these initial thoughts were understandably immature, they tell us a great deal about his mindset at this early stage:

The confining of the convicts on board the ships requires some consideration. Sickness must be the consequence of so long a voyage (six months may be allowed for the voyage, that is from the time of leaving England to the arrival in Botany Bay), and disagreeable consequences may be feared, if they have the liberty of the deck. The sooner the crimes and behaviour of these people are known the better, as they may be divided and the greatest villains particularly guarded against in one transport...

During the passage, when light airs or calms permit, I shall visit the transports to see that they are kept clean and receive the allowance ordered by government, and at these times shall endeavour to make them sensible of their situation, and that their happiness or misery is in their own hands; that those who behave well will be rewarded by being allowed to work occasionally on the small lots of land set apart for them, and which they will be put in possession of at the expiration of the time for which they are transported.'8

Phillip's persistent intervention throughout the commissioning of the fleet has also been noted. It is unlikely that he would have had the authority to detain the ships in order to ensure that the preparations were adequate, but he certainly took advantage of the delay caused by legal complications to work through details that had been overlooked.

In a final letter to his friend, Evan Nepean, the under-secretary of the Home Office, written on Friday 11 May 1787, days before sailing, Phillip apologised for having been so demanding:

Once more I take my leave of you, fully sensible of the trouble you have had in this business, for which at present I can only thank you; but at a future period, when this country feels the advantages from our intended settlement, you will enjoy a satisfaction that will I am sure make you ample amends. ${ }^{9}$

\section{Sea provisions}

By way of a case study, consider Phillip's interventions over the sea provisions. In late February, he wrote to Lord Sydney asking that more food, flour and bread in particular, be issued to the convicts and marines throughout the voyage. Wheat was then widely (but wrongly) regarded as an anti-scorbutic. ${ }^{10}$

Nepean passed the letter on to Sir Charles Middleton, the Comptroller of the Navy, who refused almost all of Phillip's demands. The convicts, he said, were supplied 
with exactly the same provisions as soldiers shipped on naval transports. Men confined on board a ship were not engaged in physical exercise and they were healthier if served with light provisions.

In any case, it was not possible to alter the rations without adding considerably to the expense of the contract, but if Phillip felt strongly enough, he could always draw on the provisions supplied for the settlement. Middleton concluded his letter with the wry observation that the convict rations must surely be better than the bread and water which he presumed was their usual diet. ${ }^{11}$

The most that the Navy Board would do was to write to William Richards, advising him of Phillip's concerns and asking him to conform to the commodore's wishes as far as possible. ${ }^{12}$ Phillip was furious and after stewing over it for several days, sent a formal protest to Lord Sydney, in the hope of protecting his reputation:

The contracts for the garrison and convicts were made before I ever saw the Navy Board on this business, and tho' I never have had it in my power officially to interfere in any respect, yet I have repeatedly pointed out the consequences that must be expected from the men's being crowded on board such small ships, and from victualling the marines according to the contract, which allows no flour, as is customary in the Navy. This must be fatal to many, and the more so as no antiscorbutics are allowed on board the transports for either marine or convict; in fact, my Lord, the garrison and convicts are sent to the extremity of the globe as they would be sent to America - a six weeks' passage.

I see the critical situation I may be in, after losing part of the garrison that is at present very weak when the service for which it is intended is considered; but I am prepared to meet difficulties, and I have only one fear - I fear, my Lord, that it may be said hereafter the officer who took charge of the expedition should have known that it was more than probable he lost half the garrison and convicts, crowded and victualled in such a manner for so long a voyage. And the public, believing it rested with me, may impute to my ignorance or inattention what I have never been consulted in, and which never coincided with my ideas, to avoid which is the purpose of this letter; and I flatter myself your Lordship will hereafter point out the situation in which I have stood thro' the whole of this business, should it ever be necessary. ${ }^{13}$

The home secretary was unmoved and the Navy Board refused to write to the Treasury recommending changes to the contract. In late April, when Phillip discovered that 17 more convicts had been embarked than had been catered for, he communicated his concerns to Middleton once again. The Navy Board replied that no supplementation was necessary since it was expected that a number of the convicts would die in the passage. ${ }^{14}$

Phillip seems to have quietly resolved that once the ships were at sea, he would take matters into his own hands. When the ships arrived at Tenerife three weeks after sailing, he directed that the convicts be given the same fresh provisions as the 
marines, explaining in a letter to Nepean that 'the allowance for the convicts when at sea being so small was the reason'. ${ }^{15}$

However, it is probable that he also spoke with William Richards before sailing, negotiating changes to the provisions that were sent on board in place of those already consumed. An undated table of provisions for the marines, filed with Home Office papers for April 1787, indicates that they were given a great deal more bread and flour than soldiers shipped across the Atlantic during the American War of Independence. ${ }^{16}$

The amount of salted beef issued to the convicts was also reduced, with bread increased from $16 \mathrm{lbs}$ to $23 \mathrm{lbs}$ a week for a mess of six men. Richards later took personal credit for having introduced these changes. ${ }^{17}$ It is possible that he initiated these changes, but he would not have done so without seeking approval. There is no correspondence in the official archives indicating that he sought permission from the Home Office or the Navy Board, and in the circumstances, it is probable that he consulted with Arthur Phillip. ${ }^{18}$

\section{Commanding the Fleet}

From a navigational perspective, the voyage from England to New South Wales was not particularly challenging. David Collins wrote that the passage south through the Atlantic was 'too beaten to afford us anything new or interesting'. ${ }^{19}$ And while the voyage from the Cape had rarely been traversed, the ships would follow Cook's Voyages, sailing eastward at around 43 degrees south latitude until they reached Van Diemen's Land, then following the coast of New South Wales north until they arrived at Botany Bay. However, close management of a convoy of 11 ships, nine of them merchant vessels, proved to be extremely challenging.

\section{Managing the Fleet}

Phillip controlled the Fleet through a system of signal flags and cannon fire laid down in charts issued to each of the masters before the fleet sailed. The signal to make more sail was a French jack at the mizzen top masthead and one shot. At night, it was three lights at the mizzen peak and eight shots, to be answered by three lights. ${ }^{20}$

Using different combinations of flags and masts, lights and shots, the commodore could warn the fleet of danger, make them sail closer together or send them into port. If the message was more complicated, Phillip would signal for the masters to come on board the Sirius to be briefed or send one of his officers around the fleet with written instructions.

The Supply was used as a utility vessel, sailing ahead as a lookout for land, remaining in-shore with a light showing when the fleet was near land, and moving around the fleet to issue instructions on how the ships were to enter harbour. Phillip 
kept the fleet in tight order, and when Collins wrote that '[the] convoy behaved well, paying more attention and obedience to signals than ships in the merchant service are commonly known to do', he was giving credit to the commodore's close management of the ships as much as the compliance of the masters. ${ }^{21}$

Each of the ships had an assigned place in the convoy, and Phillip often found it necessary to instruct them to get back in their stations. For example, on $20 \mathrm{July}$, he sent the Supply across to let the Prince of Wales know that he was greatly displeased that she did not keep to windward. Two days later, the Supply hailed the Friendship asking why she kept so far to windward and why she had not set her top gallant studding sails. ${ }^{22}$

Captain John Hunter's journal for 10 July is particularly revealing, indicating the frustration that Phillip sometimes felt when the merchantmen failed to keep their ships in order. At 7.30am that morning, the Sirius made the Supply's signal to come within hail, and at 8am the commodore 'spoke' her and instructed her 'to tear down to the Prince of Wales, and Order them to fill Salt Water and get the ship in Trim'. ${ }^{23}$

The faster ships were forever shortening sail so that they did not outstrip the rest of the fleet. The earliest mention of the Alexander doing so was at 11am on their first day at sea. By 3 o'clock that afternoon, the Charlotte was already several miles astern, and Phillip directed that she was to be taken in tow by the Hyena, a naval frigate that accompanied the convoy for several days out of Portsmouth. The challenge of keeping the ships in company would persist until the very end of the voyage. ${ }^{24}$

\section{Crew protests}

Phillip's close management of the fleet is evident in several other ways. As the ships prepared to weigh anchor on 12 May, a number of crew members on two of the merchantmen, the Alexander and the Fishburn, refused to do duty, insisting that they should be paid an advance on their wages so they could equip themselves for the long voyage ahead.

A foremastman on a First Fleet merchant ship earned good money, but based on the ancient legal doctrine that 'freight is the mother of wages', they would only be paid at the end of the voyage. A small advance had been made on sailing from the Thames, but this would have been exhausted during the long stay at Portsmouth. ${ }^{25}$ Lieutenant Philip Gidley King was sent on board from the Sirius to seek a compromise and he concluded that the protest was in some ways justified:

They had been in employ upwards of seven months, during which time they had received no pay except their River pay \& one month's advance. The great length of the voyage rendered it necessary that they should have more money, to furnish them with such necessaries as were really indispensable. But it became the masters' interest to withhold their pay from them, that they might be obliged to purchase those necessaries from them in ye course of the voyage at a very exorbitant rate. ${ }^{26}$ 
It was usual for ships' masters to operate a store, selling soap and clothing, rum and tobacco to the men on credit, and on a voyage to the far side of the world and back, this might become oppressive. ${ }^{27}$ But the law was on the masters' side and there was no time for protracted negotiation: Phillip was ready to sail, so he ordered that men who refused to do their duty should be removed to the Hyena. In the short term, they could be replaced by men from the frigate and returned once the fleet was at sea. ${ }^{28}$

\section{Shipboard discipline}

Phillip also assumed responsibility for the administration of floggings across the fleet, an intervention that would have suited the ships' officers, since it meant that the commodore was responsible for the more unpleasant aspects of shipboard discipline. A week after sailing, Phillip was informed by the master of the Scarborough and the officer commanding the marines on that ship that they had uncovered a conspiracy among the convicts. A convict informant had named ten men who had immediately been placed in double irons and given two dozen lashes to reveal the full extent of the conspiracy.

On being informed of the plot, Phillip ordered the ringleaders be sent across to the Sirius, where they were given another two dozen lashes and transferred to the Prince of Wales. The message was clear: mutiny was an offence against the fleet as a whole and not just the individual ship. Thereafter, convicts and mariners who misbehaved were sent across to the commodore to be flogged..$^{29}$

\section{Manager of a floating prison}

Of course, Phillip was not just responsible for the management of the Fleet; he was also concerned with how the convicts were supervised throughout the voyage. Managing convicts across six different vessels in the midst of the southern ocean was difficult. Doing so through a cascading system of contracts was even more challenging. However, Phillip compounded this complexity by assigning the ships' officers, the marine officers and the surgeons overlapping responsibilities, by exercising his right as commodore to take over some of the masters' functions, and by communicating his directions to the fleet through a variety of different channels.

With multiple lines of communication and substantial overlap in responsibility, there was ample opportunity for misunderstanding and wounded pride. On naval vessels, it was not unusual for the marine officers to clash with the ship's officers on questions of command, and on two of the later convict transports, duels were fought over the question of the master's authority. ${ }^{30}$

Yet on the First Fleet, there is no evidence of confusion or conflict, and while there is only limited evidence from which to draw a conclusion, the explanation seems to lie in the personal authority and the leadership style of Arthur Phillip. 


\section{Cleanliness}

The First Fleet journals are largely silent about how the prisons were cleaned, but we know from later convict ships that the bedding would have been aired and the apartments scrubbed each morning while the prisoners were on deck. On a wellregulated convict transport, the floor of the prison was scraped every day, and it was washed, smoked with gunpowder and painted with oil of tar several times a week. One of the marine officers, Watkin Tench, recalled that whilst in the tropics, they employed 'frequent explosions of gunpowder, lighting fires between decks, and a liberal use of that admirable antiseptic, oil of tar' as preventive measures. And the surgeon-general, John White, wrote that oil of tar was used three times a week and more often if necessary. ${ }^{31}$

Phillip did not get the time to visit the ships regularly as he had hoped, but he employed the military and civilian officers for this purpose. For example, John White visited the different transports on 25 June, when the fleet was first entering the tropics, and found the convicts and marines in much better health than he had expected, on account of 'the very great attention paid to cleanliness, and airing the ships'. ${ }^{32}$

\section{Removal of the men's irons}

Almost alone among the early convict transports, the male prisoners of the First Fleet were allowed the freedom of the deck, day and night. Since they were not a security threat, the women were never kept in irons unless they misbehaved.

John Hunter recalled many years later that only half of the men were allowed on the upper deck at a time, and it is possible that on some of the ships, a system was introduced to prevent the waist and forecastle from becoming overcrowded. ${ }^{33} \mathrm{But}$ David Blackburn, the sailing master on the Supply, wrote that the convicts were given permission 'to come upon deck \& take the air whenever they pleas'd during the day'. ${ }^{34}$ And Phillip wrote to Nepean:

With respect to the convicts, they have been all allowed the liberty of the deck in the day and many of them during the night, which has kept them healthier than could have been expected. ${ }^{35}$

Phillip sent written instructions to the masters of the Alexander, the Charlotte, the Friendship and the Scarborough a week after sailing, instructing them to strike the fetters from those of the men who were well behaved. (There was no need to send such a message to the other two ships since they were only carrying female convicts.)

This was a remarkable gesture, and it was possible only because of the security provided by the presence of two naval escorts, each carrying a number of marines who could be quickly deployed in case of a convict uprising. Watkin Tench wrote 
that it was done at the suggestion of some of the marine officers, and for him at least, it was a simple act of humanity. For Hunter, it was a utilitarian measure, making it easier for the men to wash and remove some of their clothes at night. But Phillip was also concerned about overcrowding and the contribution it would make to the convicts' health. ${ }^{36}$

We do not know how this instruction was applied on the Alexander, but every man on board the Charlotte was released from his irons, without exception. ${ }^{37}$ The officers on the other two ships protested because of concerns about mutiny and were temporarily exempted from the order. But when the fleet arrived at Tenerife two weeks later, Phillip directed that the convicts on these vessels were also to be freed from their irons. ${ }^{38}$

He visited each of the convict transports while they were in port and spoke to the convicts in person, explaining that he was empowered to make their life more comfortable while they were in the settlement and would look kindly on those who behaved well and made an effort at rehabilitation. ${ }^{39}$ In a letter written from Rio de Janeiro, a young convict on the Scarborough explained this policy to his parents:

Our usage is far more agreeable than I expected it would be; for we have the liberty of the deck from morning until night, and every indulgence that people in our situation could desire. Our Governor has been pleased to pay us a visit, and has promised us that every man shall be encouraged according to his behaviour. ${ }^{40}$

In large part, the low mortality rate on the First Fleet can be attributed to this liberal policy on the part of the commodore.

\section{Phillip's approach to discipline}

The punishments handed out to convicts and crew members throughout the voyage were generally mild. The most severe flogging given to any convict was the 37 lashes administered to John Bennett on the Friendship, two weeks after sailing, for breaking out of irons. It was not until Rio de Janeiro that the first corporal punishment was administered on board the Charlotte, and the first flogging did not occur on the Prince of Wales until some weeks after that. While there is no documentary evidence, it is difficult to avoid the conclusion that Phillip said something about discipline to the masters and the marine commanders prior to sailing. ${ }^{41}$

Phillip's own approach to discipline is evident from a series of incidents that occurred on board the Sirius shortly after the fleet sailed. One morning when they were about halfway to Tenerife, Phillip heard the unmistakable sound of flogging, and sent Hunter to investigate. Lieutenant George Maxwell had gone on deck that morning and discovered half of the watch missing. He had ordered the men aft and 
had each of them thrashed, declaring that they would soon be south of the Equator, where he promised to 'work up their hides'.

After hearing the men's protest, Hunter gave Maxwell a severe dressing down, but when he reported the matter to Phillip, the captain ordered all of ship's officers into his cabin, down to the boatswains' mates, where he warned them that if any of them struck a man on his ship, he would break him. The ship's officers were also forbidden to carry sticks to 'start' the men, a mild form of summary punishment commonly administered on naval vessels for laziness or neglect of duty.

Several days later, a young midshipman named Charles Ormsby ordered one of the armourer's mates to carry his hammock on deck to be aired. The older man was engaged on the captain's business and replied that he would do so shortly, whereupon Ormsby struck him, knocking out one of his teeth. The seaman immediately went onto the quarter deck and complained to Phillip, who was said to be 'very angry'. He ordered Ormsby on the quarter deck, where he was given a severe reprimand, with a warning that he would be broken if it happened again.

Phillip then ordered all hands on deck, and told the young officers in front of the men that when he was a midshipman, he had carried his own hammock on deck and they were no better than he. Since they were young gentlemen, he could not flog the midshipmen, so Phillip warned the ship's company that he would immediately punish any seaman who was found carrying a midshipman's cot.

Shortly thereafter, Phillip noticed another of the sailors taking up a midshipman's hammock and stowing it on the quarter deck. Calling the man over, he demanded to know whose bedding it was, and when it was admitted that it belonged to one of the young gentlemen, Phillip had the boatswain turn all hands on deck for a flogging. The sailor was tied up and Phillip announced to the ship's company that he was determined to punish every man who disobeyed his orders. Hunter interceded on the man's behalf, arguing that since this was his first offence he should be forgiven, whereupon Phillip ordered the man to be released with a severe warning.

It is highly unlikely that Phillip intended to punish this man. This was play-acting designed to send a message to the midshipmen and all the ship's company about how he proposed to manage his ship. We can be sure that thereafter, the midshipmen carried their own bedding on deck, and that the crew talked amongst themselves about Phillip's style of management. It is significant that this series of events was recorded in a journal kept by one of the ordinary seamen. ${ }^{42}$

\section{Convict rights}

There has been some legal commentary about the case of Kable $v$ Sinclair, the first civil court action in Australian history, in which a convict sued the master of the 
Alexander for the loss of his property on the outward voyage. The case is striking, not only because Kable won and was awarded damages, but because the case proceeded at all. Henry Kable had been convicted of a capital offence and was subject to felony attaint, which meant that, in English law, he had no standing in the courts. Phillip allowed the case to proceed because he understood that the settlement could not work if half of the residents were incapable of defending themselves in law or of giving evidence in court. ${ }^{43}$

However Phillip had already made it clear on the outward voyage that he was prepared to investigate convict complaints about their gaolers. While the fleet was at Rio de Janeiro, one of the women on the Friendship - Elizabeth Barber, a former prostitute who had behaved outrageously throughout the voyage - complained that she had been badly treated by the marines. The complaint would not have come as a surprise to the ship's officers - several weeks earlier, while she was being punished for unruly behaviour, Barber had verbally assaulted the marine captain, telling him that he could 'kiss her $\mathrm{c}^{* * *}$ '. What is surprising is not that she complained but that her protest made its way to Captain Phillip who directed Major Robert Ross, the marine commander, to go on board the Friendship to conduct an inquiry. ${ }^{44}$

\section{Conclusion}

So what do we learn from these anecdotes? Phillip was a hands-on manager, persistently intervening as the Fleet was being commissioned, to the point where his relationships with Sir Charles Middleton and his friend, Evan Nepean, were under strain. Like any good public servant, he was concerned about his reputation and left a 'paper trail' documenting his objection to certain aspects of the project in case he should be later criticised.

He managed the Fleet closely, repeatedly intervening to order the ships back into their stations, and even reprimanding the masters over how they sailed their vessels. In this and in the management of the convicts, he employed a variety of channels to communicate his directions - this could well have resulted in conflict and confusion, but for reasons that are undoubtedly associated with his personal authority, it did not.

It is possible that Phillip had experience with the transportation of convicts when he was employed by the Portuguese government, and from a voyage to India in 178384 , he understood many of the issues involved in managing men on a long-distance ocean voyage. It is also possible that he had spent time with Duncan Campbell, the last of the North American convict contractors, discussing the challenges of managing prisoners at sea. What is clear is that Phillip spent a great deal of time thinking about how he would manage the convicts in their passage to the Antipodes. 
Compared with the two tons of shipping per individual regarded as acceptable for military transports (and later adopted for the convict transports), the First Fleet was significantly over-crowded - the effective crowding ratio on the First Fleet, taking into account marines, wives and children, as well as provisions for the settlement, was 1.4 tons per men. ${ }^{45}$

Phillip's decision to allow the male convicts the freedom of the deck was undoubtedly influenced by his concern about the impact that overcrowding would have. Allowing the convicts to spend a great deal of the day on the upper deck was consistent with the prevailing view among prison reformers at the time that fresh air would prevent the spread of disease. This did not have a solid foundation in science, but by allowing the men to escape the cramped conditions of the lower deck, he reduced the likelihood that gaol fever (or typhus) would spread through the dissemination of body lice.

He recognised the importance of ensuring that the convicts and their quarters were kept clean, and while we have only limited evidence from the First Fleet journals about how this was done, it is clear that he instituted procedures that ensured that a proper routine was established.

While he was wrong about the contribution that flour and biscuits would make in keeping down the incidence of scurvy, he was attempting to improve the convict diet according to the prevailing theories of his day. When he failed to win support from the Navy Board, he seems to have worked with the convict contractor, William Richards, to quietly alter the table of rations, and when the ships touched at foreign ports, he exercised his discretion to purchase additional fresh provisions for the convicts.

He allowed the convicts to submit complaints about their treatment, instructing his officers to conduct inquiries to ascertain the facts, and on their arrival in the settlement, he permitted them to bring legal proceedings against the ships' masters over lost or stolen property.

Phillip seems to have shared the view - widely held among progressives at the time - that the convicts were capable of reform. He was evidently an optimist, granting them the freedom of the deck in the expectation that they would respond to the trust that he had placed in them. He would be disappointed in that hope, but even in the settlement, he persisted in his belief that it was possible to manage the convicts under a relatively open regime.

It is wrong to describe him as egalitarian - no naval officer of the late eighteenth century was egalitarian - but he was certainly a humanitarian, and he did not hold himself aloof from the ordinary seamen as many naval officers and merchant captains did. He went on board each of the ships at Tenerife and spoke to the prisoners in person, and it is clear from the reaction of the young convict who wrote 
home to his parents from Rio de Janeiro, that this had a powerful impact on some of them.

We see the same in his dealings with the crew of the Sirius - adopting a

psychological approach to their management. Phillip was by no means alone in this regard. He preferred to lead through example than through fear and violence.

Among the naval officers and merchant captains who managed the early convict transports, there were two strikingly different attitudes. There were those, like the convict contractor, Anthony Calvert, and his associate, Donald Trail, master of the Neptune (1790), who saw it as a percentages game. In their response to Phillip when he complained about insufficient provisions, the Navy Board indicated that it had conceived the project in actuarial terms.

But there were those for whom the objective was to arrive at their destination without losing a single convict: This is Richard Kent, the surgeon superintendent on the Boddington (1793): '...I was in hopes of carrying the most healthy set of men that ever have been carried to Port Jackson. ${ }^{46}$

Surgeon James Thomson on the Surprize (1795): 'I hope we shall be able to carry them all safe or at least land the healthiest crew ever disembarked at New South Wales'. ${ }^{47}$ Captain Patrick Campbell, the master of the Surprize: 'I sincerely hope we will land all at Port Jackson that we took on board'.48

And Mary Ann Reid, wife of the master of the Friendship (1799), wrote that her husband 'was in hopes of landing them at the place of their destination without introducing the machinery of punishment'.49

We do not have a comparable set of words penned by Arthur Phillip, but from the available evidence, it is clear that he did not adopt an actuarial mindset in the management of the 775 convicts placed in his care.

Gary L. Sturgess holds the NSW Premier's ANZSOG Chair of Public Service Delivery at the University of NSW. He is currently writing a book on the management of convict ships in the early years of transportation. 


\section{Bibliography}

Collins, David. An Account of the English Colony in New South Wales. Sydney: AH \& AW Reed, 1975.

Dann, John C, ed. The Nagle Journal: A Diary of the Life of Jacob Nagle, Sailor, from the Year 1775 to 1841. New York: Weidenfeld and Nicolson, 1988.

Dening, Greg. Mr Bligh's Bad Language: Passion. Power and Theatre on the Bounty. Cambridge: Cambridge University Press, 1992.

Doe, Helen and Harding, Richard, eds. Naval Leadership and Management. 1650-1950. Woodbridge: Boydell Press, 2012.

Easty, John. Memorandum of the Transactions of a Voyage from England to Botany Bay, 1787-1793. Sydney: Angus and Robertson, 1965.

Eder, Markus. Crime and Punishment in the Royal Navy of the Seven Years' War, 17551763. Aldershot: Ashgate Publishing, 2004.

Fidlon, Paul G and Ryan, RJ, eds. The Journal and Letters of Lt Ralph Clark, 1787-1792. Sydney: Australian Documents Library, 1981.

Fidlon, Paul G and Ryan, RJ, eds. The Journal of Arthur Bowes Smyth: Surgeon, Lady Penrhyn, 1787-1789. Sydney: Australian Documents Library, 1979.

Hunter, John, et al. An Historical Journal of Events at Sydney and at Sea, 1787-1792. Sydney: Angus and Robertson, 1968.

Irvine, Nance, ed. The Sirius Letters: The Complete Letters of Newton Fowell. Sydney: The Fairfax Library, 1988.

Neal, David. The Rule of Law in a Penal Colony. Cambridge: Cambridge University Press, 1991.

Scott, James. Remarks on a Passage to Botany Bay, 1787-1792. Sydney: Angus and Robertson, 1963.

Syrett, David. Shipping and the American War, 1775-83. London: The Athlone Press, 1970.

Tench, Watkin. Sydney's First Four Years. Sydney: Library of Australian History, 1979.

White, John. Journal of a Voyage to New South Wales. Sydney: Angus \& Robertson, 1962.

\footnotetext{
${ }^{1}$ While this story is undoubtedly apocryphal, it is has been dated back to the sixteenth century.

${ }^{2}$ Phillip to Sydney, 12 March 1787, UK National Archives, CO201/2, 120-121 and Historical Records of New South Wales (Sydney: Government Printer, 1893) vol 1, no 2, 57; Jeremy Bentham,
} 
'New South Wales: Economy', 1802, Bentham Manuscripts, University College London, box 116, 186

${ }^{3}$ Reading Mercury, 15 January 1787, 1. Based on the numbers of convicts who died before the fleet sailed, another editor thought that not one in five would make it to Botany Bay: General Evening Post, 27-29 March 1787. On the officers' attitudes: Philip Gidley King, 'Fair Copy of Remarks \& Journal Kept on the Expedition to form a Colony...', 1790, State Library of New South Wales, Safe C115, 121-123; David Collins, An Account of the English Colony in New South Wales (Sydney: AH and AW Reed, 1975), vol 1, 1; Watkin Tench, A Narrative of the Expedition to Botany Bay, London: J Debrett, 1789, $3^{\text {rd }}$ ed , reprinted in Watkin Tench, Sydney's First Four Years (Sydney: Library of Australian History, 1979), 32; Clark to Hartwell, 8 November 1787, in Paul G Fidlon and RJ Ryan eds, The Journal and Letters of Lt Ralph Clark, 1787-1792 (Sydney: Australian Documents Library, 1981), 257, Paul G Fidlon and RJ Ryan, eds, The Journal of Arthur Bowes Smyth: Surgeon, Lady Penrhyn, 1787-1789 (Sydney: Australian Documents Library, 1979), 47

${ }^{4}$ A convict transport has been defined as a ship carrying more than fifty convicts. A number of store ships carried a small number of convicts, and the risk of mutiny in those vessels, and thus the need to confine the convicts, would have been considerably lower.

${ }^{5}$ This is a conservative estimate since the ships' logs do not record all of the deaths. However, this number does include those crew members of the Alexander who were expected not to recover when the ship was in the Macassar Strait and who did not sail with the ship from Batavia.

${ }^{6}$ The one possible exception to this was Arthur Phillip himself who, according to newspaper reports in 1787 and again in 1789, had transported 400 Portuguese convicts on a voyage from Lisbon to Brazil. As yet, there is no documentary evidence to support this account: St James Chronicle, 2 February 1787; World, 16 April 1789. Of course, there were men with experience in managing hulks holding convicts or prisoners of war, but that was a somewhat different proposition, since the prisoners were regularly sent on shore to work.

${ }^{7}$ Transport Commissioners to the masters and surgeons of the Minorca, Canada and Nile, 8 June 1801, Historical Records of Australia, series 1, vol 3, 97-98; 'Instructions for the Masters and Surgeons of the Canada, Minorca and Nile, Convict Ships, at the Request of the Under Secretary of State, by Order of Lord Pelham', UK National Archives, CO201/20, 239-243a; Instructions to the masters and surgeons of convict ships, 21 February 1812; 'Instructions to Surgeons having the care of Convicts on their voyage to New South Wales', nd, 'Report from the Select Committee on Transportation', House of Commons Papers: Reports of Committees, (341) 1812, Appendices 24-27, 105-107; Instructions to the master and surgeon of the Chapman, 28 November and 3 December 1816, Historical Records of Australia, series 1, vol 9, 600-604; Instructions to the master and surgeon of the Competitor, 28 February 1823, UK National Archives, C109, 195; Instructions to the master and surgeon of the Grenada, 10 and 19 August 1824, Colonial Secretary's Papers, State Archives of New South Wales, NRS901, 4/5782, 213-232; 'Convict Vessels: Copies of Instructions to the surgeons-superintendents and the masters of convict vessels, during their voyage to foreign settlements', 23 June 1832, House of Commons Papers: Accounts and Papers, 26 February 1834, vol 47, 91-107

${ }^{8}$ Phillip to Sydney, 12 March 1787, UK National Archives, CO201/2, 88-93

${ }^{9}$ Phillip to Nepean, 11 May 1787, UK National Archives, CO 201/2, 154-5

${ }^{10}$ Phillip to Sydney, 28 February 1787, UK National Archives, CO201/2, 112-112a Historical Records of New South Wales (Sydney: Government Printer, 1893) vol 1, no 2, 50

${ }^{11}$ Middleton to [Nepean], nd, UK National Archives, CO201/2, 96-97; Historical Records of New South Wales (Sydney: Government Printer, 1893) vol 1, no 2, 91-92

${ }^{12}$ Navy Board Minutes, 28 February 1787, UK National Archives, ADM106/2623; Navy Board to Richards, 28 February 1787, UK National Archives, ADM106/2347, 208. Phillip was unhappy with this response and immediately wrote to the Home Office seeking authority to alter the provisions. Nepean passed this letter on to the Navy Board, who responded yet again that they were unable to alter the contract, although they did agree to recommend to the contractor that he issue flour in preference to rice for as long as it lasted. Phillip to Nepean, 1 March 1787, NA CO/201/2, 114-5; 
Historical Records of New South Wales (Sydney: Government Printer, 1893) vol 1, no 2, 54-5; Navy Board Minutes, 2 March 1787, UK National Archives, ADM106/2623; Navy Board to Phillip, 2 March 1787, UK National Archives, ADM106/2347, 209-210

${ }^{13}$ Phillip to Sydney, 12 March 1787, UK National Archives, CO201/2, 120-1; Historical Records of New South Wales (Sydney: Government Printer, 1893) vol 1, no 2, 56-7

${ }^{14}$ Navy Board Minutes, 25 April 1787, UK National Archives, ADM106/2623

${ }^{15}$ Phillip to Nepean, 2 September 1787, UK National Archives, CO201/2, 182a and 183

${ }^{16}$ Soldiers during the American War of Independence had been issued with $281 \mathrm{bs}$ of bread or flour a week for a mess of six men, and 2lbs of rice, and in 1794, the soldiers on board an unnamed transport received 28lbs of bread. By comparison, the marines sent to Australia were issued with 42lbs of bread. On the soldiers, see David Syrett, Shipping and the American War, 1775-83 (London: The Athlone Press, 1970), 189; Mary Ellen Condon, 'The Administration of the Transport Service During the War Against Revolutionary France, 1793-1802' (PhD dissertation, University College London, 1968), 149. On the marines, see 'Rations Provided for the Marines during their passage to Botany Bay', undated table filed with papers from April 1787, UK National Archives, CO201/2, 310; Historical Records of New South Wales (Sydney: Government Printer, 1893) vol 1, no 2,29

${ }^{17}$ William Richards, 'A Proposition for Carrying Convicts to New South Wales', enclosed with Richards to Banks, 8 August 1791, 'The Papers of Sir Joseph Banks', State Library of New South Wales, CY3008, 478-480, 508-519

${ }^{18}$ Ross to Nepean, 14 March 1787, Historical Records of New South Wales (Sydney: Government Printer, 1893) vol 1, no 2, 57-8. There is no correspondence in the archives which suggests any further involvement by government officials and Nepean might have spoken to Richards about it in person. The women convicts on the Lady Juliana would later request a variation in their rations, to have tea and sugar, foregoing some of their salt provisions, and Richards would pass their representations on to the Navy Board with his personal endorsement. Alley to Richards, 31 March 1789, UK National Archives, HO35, 10; UK National Archives, T1/667, 400-400a; UK National Maritime Museum, ADM/OT; Sydney to Treasury, 24 April 1787, enclosing a letter from Richards, UK National Archives, HO36/6, 253-257; Treasury Minutes, 24 April 1787, UK National Archives, T29/60, 317-319; [Unknown] at Port Jackson to Gentleman of Eminence in England, 24 March 1791, Historical Records of New South Wales (Sydney: Government Printer, 1893) vol 2, 773

${ }^{19}$ David Collins, An Account of the English Colony in New South Wales (Sydney: AH and AW Reed, 1975), vol 1, lxvi

20 'A List of the Commodore's Signals for the Fleet', Arthur Bowes Smyth, 'Journal of Arthur Bowes Smyth, 22 March 1787 to 8 August 1789', National Library of Australia, MS4568, 61-62. A more complete list of signals can be constructed from detailed study of the various logs and journals.

${ }^{21}$ See for example, David Collins, An Account of the English Colony in New South Wales (Sydney: AH and AW Reed, 1975), vol 1, lxxxvii and lxxxix

22 James Scott, Remarks on a Passage to Botany Bay, 1787-1792 (Sydney: Angus and Robertson, 1963), 9; Paul G Fidlon and RJ Ryan eds, The Journal and Letters of Lt Ralph Clark, 1787-1792 (Sydney: Australian Documents Library, 1981), 29

${ }^{23} \log$ of the Sirius (Hunter), UK National Archives, ADM51/832A, Part 3, 10 July 1787

${ }^{24}$ Log of the Alexander, UK National Archives, ADM51/4375, 14 May 1787. Log of the Charlotte, UK National Archives, ADM51/4375,14 and 16 May 1787; John Hunter et al, An Historical Journal of Events at Sydney and at Sea, 1787-1792 (Sydney: Angus and Robertson, 1968), 4-5; David Collins, An Account of the English Colony in New South Wales (Sydney: AH and AW Reed, 1975), vol 1, lvi; Paul G Fidlon and RJ Ryan, eds, The Journal of Arthur Bowes Smyth: Surgeon, Lady Penrhyn, 1787-1789 (Sydney: Australian Documents Library, 1979), 16; John White, Journal of a Voyage to New South Wales (Sydney: Angus and Robertson, 1962), 52; John Easty, Memorandum of the Transactions of a Voyage from England to Botany Bay, 1787-1793 (Sydney: Angus and 
Robertson, 1965), 6; James Scott, Remarks on a Passage to Botany Bay, 1787-1792 (Sydney: Angus and Robertson, 1963), 1 Following a severe storm in mid-January 1788, when the ships were only days away from their final destination, the Prince of Wales carried away her main yard and sail and the main topsail. She was so far astern that the other ships were obliged to lie to while she made her repairs - Log of the Prince of Wales, UK National Archives, ADM51/4376, 11 January 1788; Paul G Fidlon and RJ Ryan, eds, The Journal of Arthur Bowes Smyth: Surgeon, Lady Penrhyn, 1787-1789 (Sydney: Australian Documents Library, 1979), 55

${ }^{25}$ Peter Earle wrote that 'monthly pay varied according to age, rank and experience, but historians have calculated the wages of the typical foremastman throughout our period. These showed remarkable stability at around twenty-five shillings a month', except in wartime, when wages more than doubled. Peter Earle, Sailors: English Merchant Seamen, 1650-1775 (London: Methuen, 2007), 33-34. We have no details of wage rates on the First Fleet, but seamen on the Neptune (1790) were promised 27 shillings a month with a one month advance, and the provisions of an East Indiaman. See Churchill and Fletcher Statements, 'Examinations and Depositions of the several Sailors... of the Ship Neptune', UK National Archives, TS11/381, 10 and 29. Most of the seamen on the Royal Admiral (1793) were paid 26 shilling a month. See Royal Admiral, Ledger and Pay Book, India Office Records at the British Library, L/MAR/B/338P (1) and (2). On the payment of River pay and advances, see Peter Earle, Sailors: English Merchant Seamen, 1650-1775 (London: Methuen, 2007), 32; Logs of the Scarborough, 16 December 1786, Fishburn, 17 December 1786, Alexander, 29 January 1787, Lady Penrhyn, 31 January 1787, Prince of Wales, 18 February 1787, UK National Archives, ADM51/4375 and 4376

${ }^{26}$ Paul G Fidlon, et al, eds, The Journal of Philip Gidley King, Lieutenant, RN 1787-1790 (Sydney: Australian Documents Library, 1980), 7. Although Phillip makes no mention of it, John White wrote that the commodore sent King on board to resolve the differences. The detail in King's journal suggests that he played some role in seeking a resolution. See John White, Journal of a Voyage to New South Wales (Sydney: Angus and Robertson, 1962), 51; Phillip to Stephens, 12 May 1787, UK National Archives, CO 201/1/68; UK National Archives, ADM 1/2308; Historical Records of New South Wales (Sydney: Government Printer, 1893) vol 1, no 2, 103-4

${ }^{27}$ There is evidence of a store having operated on the Alexander throughout the voyage. When seaman John McGill prepared his will on 14 October 1788, he left his wages and possessions to a fellow shipmate, John Lewis, 'after Duncan Sinclair, the said Master, is paid for various articles received from him' - Will of John McGill, proved 4 June 1789, UK National Archives, PROB11/1180. On 9 July 1788, Captain Sinclair also sold two hogsheads of tobacco to Major Ross for the use of the marines, for a sum of $£ 133 / 13 /-$. This would have been from his private store for sale to the crew throughout the voyage. See Bill of Exchange and Receipt, 9 July 1788, and Ross to Stephens, 10 July 1788, UK National Archives, ADM1/3824. Lieutenant Henry Lidgbird Ball, the commander of the Supply, acted as his own purser on the First Fleet and throughout her long stay in the Antipodes, selling tobacco to most members of the crew. See Pay Book of the Supply, UK National Archives, ADM35/1826. Some details survive of the truck system operated by William Irish, the master of the Salamander, which carried stores to NSW in 1794. See State Archives of NSW, Vice Admiralty Court, Letters of Marque and Related Documents, Registrar of the Court, 1795-1812, Copy of 5/1163, Item 1, 64, 66. On these stores in general, Peter Earle, Sailors: English Merchant Seamen, 1650-1775 (London: Methuen, 2007), 33

${ }^{28}$ David Collins, An Account of the English Colony in New South Wales (Sydney: AH and AW Reed, 1975), vol 1, liv-lv

${ }^{29}$ The conspiracy was discovered on 17 May 1787. See General Evening Post, 2 June 1787; John Easty, Memorandum of the Transactions of a Voyage from England to Botany Bay, 1787-1793 (Sydney: Angus and Robertson, 1965). On the communication of the conspiracy to Phillip, see log of the Sirius (Phillip), ADM51/832A, Parts 2 and 5, 21 May 1787; $\log$ of the Sirius (Morton), UK National Archives, ADM52/2516, Parts 7 and 8, 21 May 1787; Phillip to Nepean, 20 May 1787, UK National Archives, CO201/2/160; John Hunter et al, An Historical Journal of Events at Sydney and at Sea, 1787-1792 (Sydney: Angus and Robertson, 1968) 5-6; David Collins, An Account of the English Colony in New South Wales (Sydney: AH and AW Reed, 1975), vol 1, lvii; John White, Journal of a Voyage to New South Wales (Sydney: Angus and Robertson, 1962), 52; William 
Bradley, A Voyage to New South Wales, 1786-1792 (Sydney: Public Library of New South Wales, 1969), 17; James Scott, Remarks on a Passage to Botany Bay, 1787-1792 (Sydney: Angus and Robertson, 1963), 1; John Easty, Memorandum of the Transactions of a Voyage from England to Botany Bay, 1787-1793 (Sydney: Angus and Robertson, 1965), 7-8; Nance Irvine, ed, The Sirius Letters: The Complete Letters of Newton Fowell (Sydney: The Fairfax Library, 1988), 44; Log of the Scarborough, UK National Archives, ADM51/4376, 21 May 1787; Morning Chronicle and London Advertiser, 22 August 1787. The surgeon on the Lady Penrhyn mistakenly thought the mutiny was only discovered on the 20 May when it was revealed to Phillip. Paul G Fidlon and RJ Ryan, eds, The Journal of Arthur Bowes Smyth: Surgeon, Lady Penrhyn, 1787-1789 (Sydney: Australian Documents Library, 1979), 17

${ }^{30}$ On tensions between the naval and marine officers, see Britt Zerbe, 'The Marine Officer is a Raw Lad and therefore Troublesome: Royal Naval Officers and the Officers of the Marines, 1755-1797', in Helen Doe and Richard Harding, eds, Naval Leadership and Management, 1650-1950

(Woodbridge: Boydell Press, 2012), 77-91. Thomas Gilbert, a naval officer on half pay, who had been master of the Charlotte in the First Fleet, was the original captain of the Neptune in the Second Fleet (1790). He fought a duel with Lieutenant John Macarthur, an officer of the NSW Corps, when the ship was at Plymouth. See General Evening Post, 1-3 December 1789. Edward Manning of the Pitt (1791), fought a duel with a passenger, possibly one of the soldiers, while the ship was at the Cape. See Public Advertiser, 26 April 1792

${ }^{31}$ Watkin Tench, A Narrative of the Expedition to Botany Bay, London: J Debrett, 1789, $3^{\text {rd }}$ ed, reprinted in Watkin Tench, Sydney's First Four Years (Sydney: Library of Australian History, 1979), 19-20; John White, Journal of a Voyage to New South Wales (Sydney: Angus and Robertson, 1962), 62-63. There is evidence of casks of oil of tar and vinegar being brought on board the convict transports of the First Fleet. See logs of the Prince of Wales and the Scarborough, UK National Archives, ADM51/4376, 14 April 1787. On the use of these materials at sea, see log of the Lady Penrhyn, UK National Archives, ADM51/4376, 23 June 1787. The later convict ships for which we have detailed accounts, such as the Royal Admiral (1792) and the Britannia (1796), report regular cleaning and fumigating along these lines. See log of the Royal Admiral, India Office Records at the British Library, L/MAR/B338f; Dennett to Ricketts, 21 November 1796, enclosed with 'Papers re Deaths on Board', State Archives of New South Wales, 5/1156, no 13, 118-120; Historical Records of New South Wales (Sydney: Government Printer, 1893) vol 3, 272-3

32 John White, Journal of a Voyage to New South Wales (Sydney: Angus and Robertson, 1962), 63

${ }^{33}$ John Hunter, Evidence to 'Report from the Select Committee on Transportation', Ordered to be Printed 10 July 1812, House of Commons Papers: Reports of Committees, (341) 1812, appendix 1, 18. If all of the convicts on board the Alexander were on deck at the same time, 190 men would have been packed into a space that was only 76 feet long and 31 feet wide, which would have seriously limited their opportunities for exercise. And where, as with the Charlotte and the Friendship, men and women were carried on the same ship, it is highly unlikely they would have been allowed on deck together.

${ }^{34}$ David Blackburn to Richard Knight, 12 July 1788, Letters received by Richard Knight, 12 July 1788 to 19 March 1791, State Library of New South Wales, safe 1/120. He had written to his sister from Tenerife: '... they are not now Confin'd in Irons or kept Below the Decks, Under Certain Restrictions. - Except Such As Are Refractory \&c'. See David Blackburn to Margaret Blackburn, 5 June 1787. From Rio de Janeiro, he wrote: 'None of them Are Confin'd in Chains or Even under the Deck by Day, Except Such whose Behaviour Deserves Such Punishment...' David Blackburn to Margaret Blackburn, 2 September1787, both in Blackburn Family, Letters Received from David Blackburn, 1779-1796, State Library of New South Wales, safe MLMSS 6937

${ }^{35}$ Phillip to Nepean, 2 September 1787, UK National Archives, CO201/2/184

${ }^{36}$ Watkin Tench, A Narrative of the Expedition to Botany Bay, London: J Debrett, $1789,3^{\text {rd }}$ ed, reprinted in Watkin Tench, Sydney's First Four Years (Sydney: Library of Australian History, 1979), 14; John Hunter et al, An Historical Journal of Events at Sydney and at Sea, 1787-1792 (Sydney: Angus and Robertson, 1968) 5; Phillip to Nepean, 2 September 1787, UK National Archives, CO201/2/184. Other accounts of these events can be found at David Collins, An Account 
of the English Colony in New South Wales (Sydney: AH and AW Reed, 1975), vol 1, lvi; Paul G Fidlon and RJ Ryan eds, The Journal and Letters of Lt Ralph Clark, 1787-1792 (Sydney: Australian Documents Library, 1981), 13; David Blackburn to Richard Knight, 12 July 1788, Blackburn Letters, State Library of New South Wales, safe 1/120; William Bradley, A Voyage to New South Wales, 1786-1792 (Sydney: Public Library of New South Wales, 1969), 17; Nance Irvine, ed, The Sirius Letters: The Complete Letters of Newton Fowell...(Sydney: The Fairfax Library, 1988), 41

${ }^{37}$ Watkin Tench, A Narrative of the Expedition to Botany Bay, London: J Debrett, $1789,3^{\text {rd }}$ ed, reprinted in Watkin Tench, Sydney's First Four Years (Sydney: Library of Australian History, 1979), 14

${ }^{38}$ Phillip to Nepean, 5 June 1787, UK National Archives, CO201/2/168-169; Log of the Scarborough, 3 June 1787, UK National Archives, ADM51/4376; John Easty, Memorandum of the Transactions of a Voyage from England to Botany Bay, 1787-1793 (Sydney: Angus and Robertson, 1965), 11; Paul G Fidlon and RJ Ryan eds, The Journal and Letters of Lt Ralph Clark, 1787-1792 (Sydney: Australian Documents Library, 1981), 16

39 'Letter from an Officer on board the Fleet bound to New South Wales', Whitehall Evening Post, 26 January 1788

40 'Copy of a Letter from a Young Man, one of the Convicts in the Fleet sent to Botany Bay, to his Parents', Public Advertiser, 27 March 1788

${ }^{41}$ Paul G Fidlon and RJ Ryan eds, The Journal and Letters of Lt Ralph Clark, 1787-1792 (Sydney: Australian Documents Library, 1981), 14; John White, Journal of a Voyage to New South Wales (Sydney: Angus and Robertson, 1962), 88; James Scott, Remarks on a Passage to Botany Bay, 1787-1792 (Sydney: Angus and Robertson, 1963), 17, and inside back cover. George Worgan, the surgeon on the Sirius, commented after their arrival at Port Jackson that the convicts made it difficult for Phillip to persist with his policy of leniency. See George B Worgan, Journal of a First Fleet Surgeon (Sydney: Library of Australian History, 1978), 36. See also Daniel Southwell, Journal, Southwell Papers, BL Add Mss 16381, 7 February 1788, and Historical Records of New South Wales (Sydney: Government Printer, 1893) vol 2, 665

42 John C Dann, ed, The Nagle Journal: A Diary of the Life of Jacob Nagle, Sailor, from the Year 1775 to 1841 (New York: Weidenfeld and Nicolson, 1988), 85-86. The deliberate use of drama in the remission of punishment as a way of teaching the men is discussed in Markus Eder, Crime and Punishment in the Royal Navy of the Seven Years' War, 1755-1763 (Aldershot: Ashgate Publishing, 2004), 142-143. Dening discusses the psychology of leadership on board a naval vessel in Greg Dening, Mr Bligh's Bad Language: Passion, Power and Theatre on the Bounty (Cambridge: Cambridge University Press, 1992)

${ }^{43}$ The legal issues involved in Kable $v$ Sinclair are discussed in David Neal, The Rule of Law in a Penal Colony (Cambridge: Cambridge University Press, 1991), 1-7

${ }^{44}$ Paul G Fidlon and RJ Ryan eds, The Journal and Letters of Lt Ralph Clark, 1787-1792 (Sydney: Australian Documents Library, 1981), 35

45 The effective crowding ratio includes all of the convicts, soldiers and other passengers, and their wives and children, and deducts the tonnage of stores and provisions for the settlement from the measured tonnage of the ship.

${ }^{46}$ Kent to Nepean, 18 March 1793, UK National Archives, HO42/25, 160-161a

${ }^{47}$ Thomson to King, 4 August 1795, UK National Archives, CO201/11, 204a

${ }^{48}$ Campbell to Navy Board, 2 August 1794, UK National Archives, CO201/12, 174-175

${ }^{49}$ Mary Anne Reid, 'Cursory Remarks on Board the Friendship', Asiatic Journal, November 1819, 455 